\title{
Tomato Grafting: A Global Perspective
}

\author{
Hira Singh \\ Department of Vegetable Science, Punjab Agricultural University, Ludhiana \\ 141004 , India \\ Pradeep Kumar \\ ICAR - Central Arid Zone Research Institute, Jodhpur 342003, India
}

Sushila Chaudhari

Department of Crop and Soil Sciences, North Carolina State University, Raleigh, NC 27695

Menahem Edelstein ${ }^{1}$

Agricultural Research Organization, Newe Ya'ar Research Center, P.O. box 1021, Ramat Yishay 30095, Israel

Additional index words. abiotic stress, biotic stress, fruit quality, tolerance, yield enhancement

Abstract. Grafting of vegetable seedlings is a unique horticultural technology practiced for many years in East Asia to overcome issues associated with intensive cultivation using limited arable land. This technology was introduced to Europe and other countries in the late 20th century along with improved grafting methods suitable for commercial production of grafted vegetable seedlings. Tomato grafting is becoming a welldeveloped practice worldwide with many horticultural advantages. The primary motivation for grafting tomato has been to prevent the damage caused by soilborne pathogens under intensive production system. However, recent reports suggest that grafting onto suitable rootstocks can also alleviate the adverse effects of abiotic stresses such as salinity, water, temperature, and heavy metals besides enhancing the efficiency of water and nutrient use of tomato plants. This review gives an overview of the scientific literatures on the various aspects of tomato grafting including important steps of grafting, grafting methods, scion-rootstock interaction, and rootstock-derived changes in vegetative growth, fruit yield, and quality in grafted plants under different growing conditions. This review also highlights the economic significance of grafted tomato cultivation and offers discussion on the future thrust and technical issues that need to be addressed for the effective adoption of grafting.

Tomato (Solanum lycopersicum L.) is one of the most important and popular vegetable crops in the world. The current world tomato production is 170.7 million tons from an area of 5 million hectares (FAOSTAT, 2014). Tomato is produced and consumed worldwide, grown in both open-field and protected conditions, in soil or soilless media. However, production of this crop is facing many challenges including abiotic and biotic stresses. Efforts are being made by public and private sectors to develop tomato cultivars with the ability to perform optimally under constraint conditions through breeding and biotechnological tools, although these require considerable time. One alternative approach is grafting, which emerged as a potential tool to quickly enhance the efficiency of high-yielding genotypes for wider adaptability or resistance to different stresses (Kumar et al., 2017). Vegetable grafting has become a potential tool in boosting the

Received for publication 4 Apr. 2017. Accepted for publication 21 Aug. 2017.

Contribution number 12017 from the Agricultural Research Organization, the Volcani Center, Bet Dagan, Israel, is duly acknowledged.

${ }^{1}$ Corrresponding author. E-mail: medelst@volcani. agri.gov.il.
2013), and heavy metals (Kumar et al., 2015a, 2015b, 2015c), and also to enhance water-use efficiency (Cohen and Naor, 2002; Kumar et al., 2017), nutrient uptake (Goto et al., 2013), fruit yield (KacjanMarsic and Osvald, 2004; Khah et al., 2006; Pogonyi et al., 2005; Turhan et al., 2011), and quality (Flores et al., 2010; Kacjan-Marsic and Osvald, 2004). Therefore, the aim of using grafting techniques in tomato is to enhance fruit production without any nutritional decline and to reduce susceptibility to various abiotic and biotic stresses. This review summarizes the available scientific information about the effects of grafting on enhancing the yield and quality of tomato under specific conditions and discussing the process and methods of tomato grafting. In addition, there is a discussion of the economic aspects and technical issues that need to be improved in order to expand the use of grafted tomato plants.

\section{Tomato Grafting}

For effective and successful grafting, Lee et al. (2010) suggested following four consecutive steps: 1) selection of rootstock and scion, 2) creation of a graft union by physical manipulation, 3) graft union healing, and 4) acclimatization of the grafted plant.

Selection of rootstock and scion. Every rootstock has its own effect in combination with the scion and can perform differently in different environmental conditions, so the choice of both scion and rootstock is critical for achieving the goal (Goto et al., 2013; Guan et al., 2012; Lee, 1994). Grafting success depends on many factors, but genotypic factors are considered to be the most important for compatibility or incompatibility of the scion and rootstock. It is evident that some graft combinations have a positive effect on vegetative growth and development whereas others have a negative effect that can result in growth suppression (Huh et al., 2003) and reduced yield (Yetisir et al., 2003) and fruit quality (Davis et al., 2008a). Graft incompatibility can occur despite a successful graft and may be attributed to factors such as weak graft union, failure of the grafted plants to grow, physiological incompatibility (due to lack of cellular recognition, wounding responses, and effects of growth regulators), or production of incompatibility toxins (Davis et al., 2008b). In general, taxonomically closer scion and rootstock have higher graft compatibility (Wang, 2011). In solanaceous crops, the use of both intraspecific (of the same species) and interspecific (closely related species) grafting is well documented (Black et al., 2003; Chaudhari et al., 2016a; Gousset et al., 2005; Lin et al., 2004; Petran and Hoover, 2014) in cultivated or wild relatives. Petran and Hoover (2014) reported that $S$. torvum (wild eggplant) show moderate compatibility as rootstock with cultivated tomato. Other studies have documented $S$. sisymbriifolium, $S$. torvum, S. intergrifolium, and S. toxicurium as superior rootstocks for tomato and displaying 
Table 1. Percentage of grafted tomato cultivation to the total area of tomato cultivation in different countries.

\begin{tabular}{lccc}
\hline Country & $\begin{array}{c}\text { Total tomato } \\
\text { cultivation area (ha) }\end{array}$ & $\begin{array}{c}\text { Total tomato } \\
\text { cultivation area (ha) }\end{array}$ & $\begin{array}{c}\text { Percent area under grafted } \\
\text { tomato cultivation }\end{array}$ \\
\hline China & $850,933^{\mathrm{z}}$ & $1,001,711^{\mathrm{y}}$ & $1^{\mathrm{x}}$ \\
United States & $162,580^{\mathrm{z}}$ & $163,380^{\mathrm{y}}$ & $18 \mathrm{mgp}^{\mathrm{v}}$ \\
Italy & $115,477^{\mathrm{z}}$ & $103,171^{\mathrm{y}}$ & $15.1 \mathrm{mgp}^{\mathrm{w}}$ \\
Spain & $54,868^{\mathrm{z}}$ & $54,750^{\mathrm{y}}$ & $72.8 \mathrm{mgp}^{\mathrm{w}}$ \\
Japan & $12,500^{\mathrm{z}}$ & $12,100^{\mathrm{y}}$ & $40^{\mathrm{w}}$ \\
Korea & $8,383^{\mathrm{z}}$ & $8,513^{\mathrm{y}}$ & $25^{\mathrm{w}}$ \\
France & $8,513^{\mathrm{z}}$ & $2,990^{\mathrm{y}}$ & $50^{\mathrm{w}}$ \\
Netherlands & $1,600^{\mathrm{z}}$ & $1,780^{\mathrm{y}}$ & $75^{\mathrm{w}}$ \\
Vietnam & - & $60,000^{\mathrm{w}}$ & $33.3^{\mathrm{w}}$ \\
\hline
\end{tabular}

Tomato cultivation area from FAO statistics ( ${ }^{\mathrm{z} F A O S T A T, ~ 2008, ~}{ }^{\mathrm{y}} 2014$; ${ }^{\mathrm{x}} \mathrm{Huang}$ et al., 2015b; ${ }^{\mathrm{w}} \mathrm{Lee}$ et al., 2010; 'Kubota, 2015) (Source: Modified after Lee et al., 2010).

mgp $=$ million grafted plants .

great resistance to various diseases (Goto et al., 2013; Kawaguchi et al., 2008; Matsuzoe et al., 1993b; Oda et al., 1996, 2005). Furthermore, the successful intergeneric tomato grafting was reported with rootstock 'Goji berry' (Lyceum chinense) in China by Huang et al. (2015b) and tobacco (Nicotiana tabacum 'Samsun' and Nicotiana rustica 'Hasankeyf') in Turkey by Iseri et al. (2015).

It has been shown that the tomato plants' tolerance to abiotic and biotic stresses (Altunlu and Gul, 2012; Colla et al., 2013; McAvoy et al., 2012) and fruit quality and yield are affected by the type of rootstock and scion used (Flores et al., 2010; KacjanMarsic and Osvald, 2004; Kumar et al., $2015 b, 2015 c)$. Therefore, thorough investigation is required before selection of scion and rootstock genotypes for grafting to achieve aimed goal. Some of the characteristics of grafting tomato onto different solanaceous rootstocks are summarized in Table 2.

Grafting methods. The grafting method, skills, and ideal post-grafting environmental conditions for proper healing and acclimatization are very important for the production of grafted plants (Lee, 1994). The commonly used grafting methods in tomato are tube and cleft grafting (Lee and Oda, 2003); however, tube grafting (also known as splice grafting, top grafting, and slant-cut grafting) is more popular and currently used worldwide among progressive vegetable growers and commercial nurseries (Hanna, 2012; Lee and Oda, 2003; Oda, 1995; Rivard and Louws, 2006; $\mathrm{Vu}$ et al., 2015). This method ensures a strong vascular connection between the scion and rootstock at graft union, and is known to generate high-quality and sturdy grafted plants which is required for mechanical transplanting (Bausher, 2013). Tube grafting is a highly-effective and relatively quick procedure to produce grafted plants (Rivard and Louws, 2006). Kubota et al. (2008) demonstrated that one worker can produce $300-500$ grafted plants/h depending on efficiency and skills. To reduce grafting labor costs and increase the efficiency of grafted seedling production, grafting robots have been proposed as an alternative (Lee, 2003).

Tomato seedlings are grafted when the stem diameter reaches $\approx 1.5$ to $2.5-\mathrm{mm}$ (Bumgarner and Kleinhenz, 2014; Rivard and Louws, 2006). It is important that the seedlings are healthy and uniform in size at the time of grafting. To make a graft, the top part of the scion and rootstock is severed at a 45- to 70-degree angle, and then the upper part of the scion and lower part of the rootstock is held together with an ordinary clip, an elastic tube-shaped clip with a side slit, or a ceramic pin, in a way that allows their vascular tissue to grow together and form a strong union for water and nutrient uptake (Bausher, 2013). The illustration of tube grafting method is given in Fig. 1.

In South Korea, Vu et al. (2015) observed that the position of grafting on rootstock had no influence on plant survival, either grafting was performed above or below the cotyledons. However, the position of grafting on rootstock influenced the growth of grafted plants. Plants having graft union above rootstock cotyledons exhibited significantly higher seedling growth in terms of stem diameter and fresh and dry shoot biomass compared with plants had graft union below rootstock cotyledons. However, grafting above the rootstock cotyledons have the issue of shoot regrowth from the rootstock in full season crop which requires frequent removal of regrowth (Bausher, 2011) which may incur extra labor costs. Therefore, grafting tomato below rootstock cotyledons is recommended to eliminate rootstock regrowth.

Acclimatization of the grafted plant. Acclimatization involves healing of the graft union and hardening of plants before planting in the field or greenhouse; this stage is critical for the survival of the grafted plants (Lee and Oda, 2003). Immediately after grafting, plants should be transferred to a healing chamber to form callus and reconnect the vascular bundles of the scion and rootstock. For the first 24 to $48 \mathrm{~h}$, the plants should be kept under low light intensity to reduce transpiration and evaporation (Rivard and Louws, 2006). Relative humidity (RH) should be maintained between $85 \%$ and $100 \%$; high RH decreases scion transpiration rate which prevents it from drying out (Johnson et al., 2011). The temperature inside the healing chamber should be in the range 25 to $30{ }^{\circ} \mathrm{C}$ (Lee, 2007; Oda 2007). After 2 or $3 \mathrm{~d}$, the RH is gradually reduced and the light inside the graft-healing chamber is increased, but keeping the potting media moist. High $\mathrm{RH}$ for a prolonged period may result in the development of adventitious roots from scion which become a source of entry for soilborne pathogens if it remains intact after transplanting into the field. The gradual decrease in $\mathrm{RH}$ and increase in light should take place over 4-8 d. The plants are ready to grow under normal greenhouse conditions 6-10 d after grafting, and with an increase in stem girth, the grafting clip or tube usually drops off itself (Guan and Hallet, 2016).

\section{Grafting Significance in Tomato}

Yield and fruit quality. The main focus of researchers is to identify different tomato rootstocks that tolerate or resolve regional issues affecting the growth and productivity of plants (Kubota et al., 2008; Louws et al., 2010). Rootstocks may affect the growth and yield of scion plants either positively or negatively. Kacjan-Marsic and Osvald (2004) obtained significantly higher (27\%) fruit yield per plant when tomato scion 'Monroe' was grafted onto 'Beaufort' rootstock, whereas the fruit yield decreased by $33 \%$ with the use of scion 'Belle' as compared with their respective nongrafted plants. Scientists have reported the benefits of grafting on yield increase, under both stress and nonstress conditions, which mainly depends on the rootstock genotype (Chetelat and Petersen, 2003; Kacjan-Marsic and Osvald, 2004; Khah et al., 2006; Leonardi and Giuffrida, 2006; Pogonyi et al., 2005). Khah et al. (2006) demonstrated that the tomato scion 'Big Red' grafted onto the 'He-man' tomato rootstock produced higher total yield in open-field and greenhouse without any significant effects on fruit quality characteristics. Similarly, Pogonyi et al. (2005) reported an increased yield using 'Lemance' tomato scion grafted onto 'Beaufort' rootstock. This yield increase in grafted tomato was mainly due to higher fruit biomass and greater number of fruits per plant than nongrafted plants. Grafting a fusarium-susceptible heirloom tomato 'German Johnson' scion with 'Maxifort' rootstock resulted in significantly higher yield with no symptoms of fusarium wilt (Rivard and Louws, 2008). In the United States, Lopez-Perez et al. (2006) obtained significantly higher yield when a susceptible tomato 'Blitz' scion was grafted onto a nematoderesistant rootstock 'Beaufort' compared with nongrafted plants.

Researchers have observed variable effects of grafting on tomato fruit quality. Kumar et al. (2015b) demonstrated that fruit quality traits such as skin color, fruit shape index, titratable acidity (TA), soluble solids content (SSC), and dry matter content are positively affected by the rootstock. Turhan et al. (2011) observed that the tomato fruit quality attributes such as lycopene content and $\mathrm{pH}$ were not changed with grafting, whereas vitamin $\mathrm{C}$, TA, and SSC were decreased in grafted plants. Vrcek et al. (2011) reported that vitamin $\mathrm{C}$, total phenolics, and total antioxidant activity in tomato declined because of grafting. 
Table 2. Solanaceous rootstocks for grafting tomato for specific purpose in different countries.

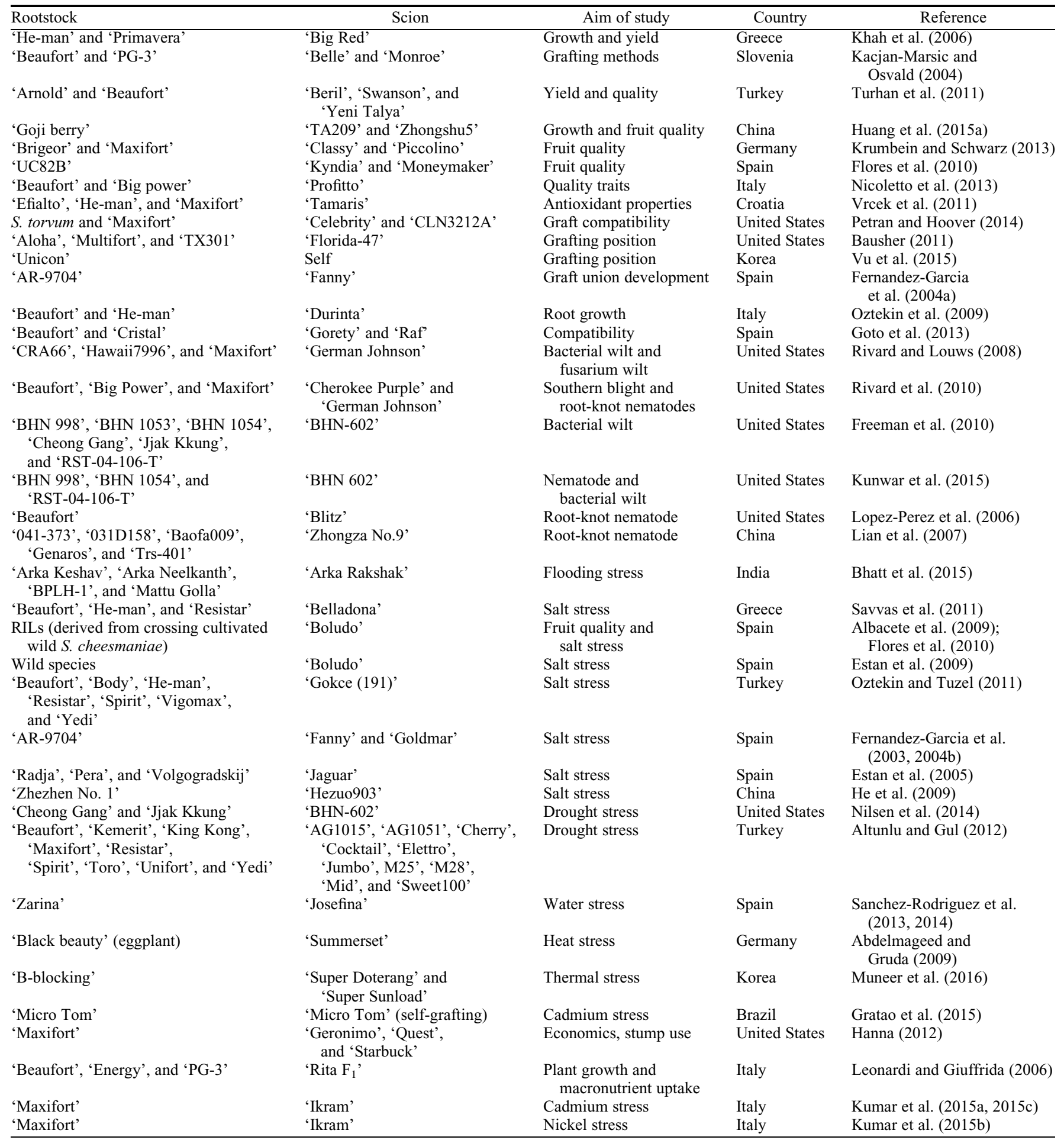

Abiotic stresses can negatively affect crop yield, but these can enhance fruit quality attributes by using grafting plants (Kumar et al., 2015b). In Greece, Savvas et al. (2011) claimed that salinity improved TA, total soluble solids (TSS), and vitamin C contents in tomato fruits, whereas grafting and rootstock had no effect on any quality characteristics. In Spain, Flores et al. (2010) demonstrated that grafting had no effect on tomato yield under standard growing conditions; however, under saline conditions, grafting significantly affected the fruit quality of fresh and processed tomato by enhancing TA and SSC. In Italy, Kumar et al. (2015b) found that excess nickel $(\mathrm{Ni}, 50$ $\mu \mathrm{M}$ ) in the rooting medium depressed the growth and fruit yield of nongrafted tomato 'Ikram', self-grafted or grafted onto different rootstocks. In contrast, some fruit quality characteristics including fruit firmness, brightness, TSS, and dry matter content were enhanced under $\mathrm{Ni}$ stress regardless of the graft combination. Krumbein and Schwarz
(2013) demonstrated that the enhancement of carotenoids (lycopene and $\beta$-carotene) and flavor compounds (sugars, acids, and aroma volatiles) in tomato fruits grown under shaded condition depends on rootstock-scion combinations. In summary, the quality characteristics of grafted tomato fruits are greatly influenced by rootstock-scion combinations, growing system, and environmental conditions.

Management of soilborne diseases. Continuous cropping on the same field is inevitable 


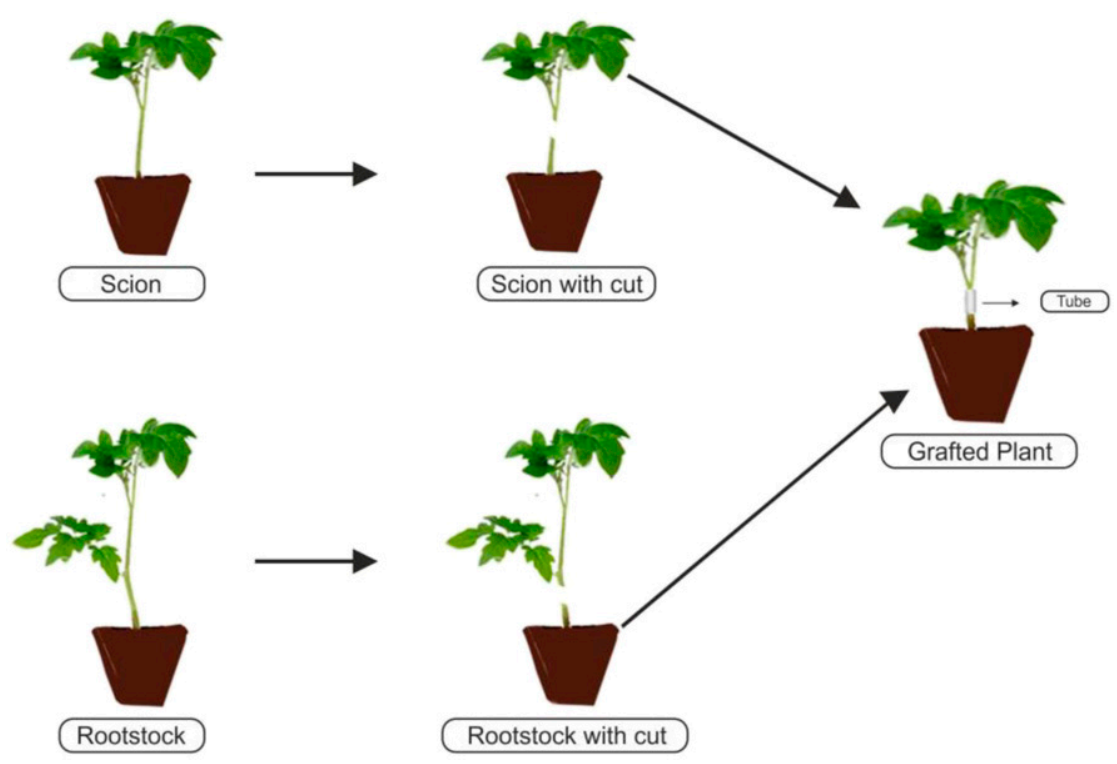

Fig. 1. Illustration of "tube grafting" method in tomato.

in vegetable production because of limited availability of arable land. Soilborne diseases incited by pathogens such as Fusarium oxysporum f.sp. lycopersici, Ralstonia solanacearum, Verticillium dahliae, and nematodes are major threats in intensive tomato cultivation and are difficult to manage (Rivard and Louws, 2008). Grafting is potentially a new alternative to methyl bromide for the control of soilborne pathogens of tomato (Louws, 2012; Louws et al., 2010; McAvoy et al., 2012). In the United States, Rivard and Louws (2008) reported no symptoms of fusarium wilt when heirloom tomato 'German Johnson' scion was grafted onto rootstock 'Maxifort'. Tomato rootstock 'Big Power', 'Beaufort', and 'Maxifort' were tested to manage southern blight in fields naturally infested with Sclerotium rolfsii (Rivard et al., 2010), and reported $0 \%$ to $5 \%$ disease incidence and lower area under the disease progress curve among grafted plants than nongrafted or self-grafted plants.

Tomato bacterial wilt, incited by Ralstonia solanacearum, can be a serious threat for tomato production because of complex pathogen biology and lack of efficient mana gement measures (Rivard et al., 2012). Moreover, resistance to bacterial wilt is quantitative and strongly influenced by the environment and therefore difficult to develop tolerant cultivars (Scott et al., 2005). Thus, grafting using appropriate rootstock has been exploited well to manage bacterial wilt in tomato (Lin et al., 2008; Matsuzoe et al., 1993a; Rivard et al., 2012), and has been proposed for openfield and protected cultivation (King et al., 2008). Rivard and Louws (2008) found that rootstock 'CRA 66' and 'Hawaii 7996' (breeding lines) were the most promising for managing bacterial wilt. Furthermore, scion of 'BHN 602' grafted onto 'BHN 1054', 'Cheong Gang', 'BHN 998', or 'RST-04106-T' exhibited tolerance to bacterial wilt (McAvoy et al., 2012).
Grafting may cause a shift in the host specificity of the pathogen, emergence of a new pathogen, or both when a specific rootstock is used continuously for a long period of time in the production system (Garibaldi et al., 2008; Gilardi et al., 2014; Rivard et al., 2010). According to a survey done in Italy during the early 2000s, symptoms of necrosis and deterioration of roots were noticed on grafted and nongrafted tomato plants. It was due to brown root rot incited by Colletotrichum coccodes which reappeared after the replacement of methyl bromide with grafting. Gilardi et al. (2014) tested 19 tomato genotypes against $C$. coccodes in naturally infested soil and found that rootstock such as 'Arnold', 'Armstrong', 'Big Power', and 'Beaufort' showed higher resistance. However, in an earlier study, rootstock 'He-man' and 'Energy' were found more tolerant than 'Beaufort', which rather appeared sensitive to $C$. coccodes infestation (Minuto et al., 2008).

Nematode management. In tomato production, root-knot nematode (Meloidogyne spp.) causes great damage to plants, especially in sandy soils and protected cultivation. Chemical control is a common practice for controlling nematodes, but there is great need for an alternate method to avoid excessive use of chemicals. Nematode resistance in tomato is controlled by the single dominant $M i-1$ gene which is present in the wild tomato L. peruvianum (Medina-Filho and Stevens, 1980), although the resistance is prone to break down under high soil temperatures at $>32{ }^{\circ} \mathrm{C}$ (Williamson, 1998). Recent studies demonstrated that the grafting is a sustainable and ecofriendly practice for nematode management. In the United States, Rivard et al. (2010) studied the response of tomato rootstock 'Big Power', 'Beaufort', and 'Maxifort' in management of root-knot nematodes in naturally infested soils and reported significant differences in root galling and root-knot nematode populations among rootstocks. Rootstock 'Big Power' had minimal root galling and nematode infestation whereas rootstock 'Beaufort' and 'Maxifort' had a similar level of root galling as in nongrafted or self-grafted plants. Lopez-Perez et al. (2006) also observed that resistant rootstocks retained their yields under high nematode densities, but significant differences were reported in root galling and final nematode populations between rootstocks. Kunwar et al. (2015) demonstrated the use of grafting for managing root-knot nematodes in susceptible scion 'BHN 602' using bacterial wilt-resistant tomato rootstocks (RST-04-106-T, BHN 998, and BHN 1054) which represents the potential of grafting for managing multiple soilborne pathogens using the similar rootstocks. It can be concluded that grafting can be one of the best alternatives for sustainable crop productivity in nematode-infested soils.

Parasitic plants and herbicide tolerance. One aspect of weed management in grafted tomato relates to the ability of grafted plants to compete with weeds. Although grafted tomato is considered more vigorous than nongrafted tomato (Kacjan-Marsic and Osvald, 2004; Khah et al., 2006), grafting has no apparent advantage or disadvantage in weed competitiveness or suppressing weed growth. Previous studies showed no difference in the biomass of weeds between grafted and nongrafted tomato (Chaudhari et al., 2016b; Ghosheh et al., 2010), indicating that grafting in tomato does not eliminate the need for timely application of herbicides, intensive hand-weeding, or both. However, grafting has been found to have a positive impact on management of parasitic weeds such as broomrape species (Phelipanche aegyptiaca and $P$. ramosa). Dor et al. (2010) demonstrated that resistant rootstock significantly reduced broomrape infections when grafted to either a susceptible or resistant (self-graft) scion.

The other challenging aspect of weed management is to know the tolerance of grafted plants to herbicides which are registered to use for weed control in nongrafted crops. Previous research reported that the effect of grafting on herbicide tolerance depends on the herbicide and rootstock-scion combinations (Chaudhari et al., 2015, 2016a, 2017a, 2017b; Ghosheh et al., 2010). Chaudhari et al. (2015) found similar effects with regard to injury caused by herbicide (fomesafen, halosulfuron, metribuzin, napropamide, $S$-metolachlor, and trifluralin) application (pre- and posttransplants) in both nongrafted and grafted tomato plants. Chaudhari et al. (2017b) also reported that grafted and nongrafted tomato plants under drought stress exhibit similar tolerance to metribuzin. However, Ghosheh et al. (2010) reported that grafted tomato under greenhouse conditions had relatively higher sensitivity to a mixture of metribuzin and sethoxydim applied after transplant compared with nongrafted plants. The possible explanation for the different responses of grafted tomato plants to herbicides in these studies could be due to different rootstock-scion 
combinations and time when injury was reported after herbicide application. Weed management with herbicides can be more challenging in interspecific grafting using a rootstock and scion from different species of solanaceous crops. Rootstock tolerance to herbicides may or may not confer its benefits to the entire plant. Tomato tolerance of the herbicides metribuzin and halosulfuron was not conferred to the eggplant scion when tomato was used as a rootstock; however, these herbicides are safe to use in tomato crops (Chaudhari et al., 2016a). Chaudhari et al. (2017b) reported that grafting did not affect absorption, translocation, and metabolism of postapplied halosulfuron in tomato and eggplant. To better incorporate grafted tomato into production systems, herbicide evaluation programs would need to include tolerance data to both the rootstock and scion to reduce the potential economic loss due to herbicide injury in grafted plants.

Salinity tolerance. Traditional breeding methods have been employed to improve salt tolerance in tomato, but limited success is achieved because of the genetically and physiologically complex nature of the salttolerant traits (Cuartero and Fernandez, 1999; Flowers, 2004). Grafting has been demonstrated as a simple and cheap technique to improve adaptation of tomato plants to salt stress (Colla et al., 2010; Estan et al., 2005; Santa-Cruz et al., 2001, 2002). Studies showed significant yield increase in grafted plants (up to $80 \%$ ) compared with nongrafted and self-grafted tomato plants under saline conditions (Estan et al., 2005, 2009). In Greece, Savvas et al. (2011) demonstrated that the effect of grafting on tomato fruit yield depends on the rootstock and the level of salinity. The yield improvement is contributed to the ability of rootstock to maintain lower concentration of chloride and sodium ions in the leaves (Cuartero et al., 2006). Albacete et al. (2009) observed that the enhanced fruit yield of grafted plants under salinity was associated with the supply of root-derived ionic and hormonal factors that regulate leaf area and senescence. In China, He et al. (2009) demonstrated that the salt stress-induced shoot damage in grafted plants using tolerant rootstock 'Zhezhen No.1' was lower than nongrafted 'Hezuo903' or selfgrafted tomato; the response of grafted plants was related to the improvement of photosynthesis and enhancement of antioxidant enzyme activities. Recently, the effectiveness of tobacco as a rootstock to confer salinity $(\mathrm{NaCl})$ tolerance to tomato scion 'Elazig' was explored by Iseri et al. (2015). Tobacco roots showed better adaptive responses to salt stress compared with tomato as indicated by changes in proline and antioxidant enzyme [ascorbate peroxidase (APX) and catalase (CAT)] levels.

Thermal stress tolerance. In arid and semiarid regions, high temperatures and low humidity adversely affect the vegetative and reproductive growth of tomato and eventually diminish the yield and fruit quality. Higher temperatures during the day, night, or both adversely affect fruit set (Abdelmageed and Gruda, 2007, 2009). Root development was found to be more sensitive to high temperature $\left(>30{ }^{\circ} \mathrm{C}\right.$ soil temperature $)$ than shoot growth (Rylski, 1972). Thus, the use of heat-tolerant rootstock can be an alternative approach for overcoming high temperature stress. Tomato scion 'Tmknvf2' grafted onto ' $\mathrm{RX}-335$ ' rootstock had performed better in terms of vegetative growth at an higher temperature $\left(35^{\circ} \mathrm{C}\right)$ than nongrafted plants (Rivero et al., 2003a, 2003b). Similarly, in Germany, Abdelmageed and Gruda (2009) documented the positive effects of grafting when tomato scion 'UC 82-B' grafted onto heat-tolerant tomato 'Summerset' or eggplant 'Black Beauty' rootstock under high temperature stress. They reported improved vegetative growth (higher biomass), higher chlorophyll fluorescence, greater leaf area and dry biomass, higher pollen grains per flower, and lower electrolyte leakage in grafted plants than nongrafted plants. Although above graft combination had a positive effect on plant growth attributes, the increase in fruit yield was not remarkable. Thus, it necessitates the testing of suitable combination of rootstock and scion for heat tolerance not only for vegetative growth but also for reproductive performance.

Suboptimal temperature is one of the major concerns for successful tomato cultivation in nonheated greenhouses in temperate regions (Schwarz et al., 2010). Low temperature (below $10{ }^{\circ} \mathrm{C}$ ) was found to adversely affect the vegetative growth of tomato by shortening internodes, reduced leaf expansion, leaf number, and total leaf fresh biomass (Venema et al., 1999). The lower temperature during reproductive growth stage was also found to negatively affect the formation of reproductive organs such as flowers, reduce fruit and seed setting and as a result, eventually diminish the tomato yield and fruit quality (Van der Ploeg and Heuvelink, 2005). The use of coldtolerant rootstock for grafting has been demonstrated as one of the best alternatives to overcome the low temperature stress in tomato (Ntatsi et al., 2014; Riga, 2015; Venema et al., 2008). Venema et al. (2008) reported that tomato breeding line 'LA 1777' $(S$. habrochaites) when used as a rootstock improved cold tolerance in grafted plants by mainly increasing the root mass ratio compared with nongrafted plants. The adaptation of grafted plants onto 'LA 1777' was attributed to the higher level of antioxidant compounds in tomato shoots as a consequence of significantly higher levels of soluble carbohydrates, total amino acids, guaiacol peroxidase (GPX) activity in leaves and fruits, and superoxide dismutase activity in fruits (Ntatsi et al., 2014). Furthermore, Ntatsi et al. (2011) demonstrated that rootstock which induces abscisic acid production could significantly reduce photoinhibition and improve tomato growth rate under cold stress.

Water stress tolerance. Water stress is one of the most widespread and frequent abiotic stresses which may drastically affect plant growth and development in many vegetable crops. Using various breeding and biotechnological approaches, water stress-tolerant or resistant tomato cultivars may be achieved, although such approaches demand a very long time period to produce desired cultivars. Therefore, researchers reported that grafting is one of the rapid alternative approaches to achieve water stress tolerance in tomato (Nilsen et al., 2014). According to Kumar et al. (2017), a promising strategy to enhance yield stability under water stress conditions is the selection of rootstock with constitutive potential to increase yield rather than plant survival. In Spain, SánchezRodríguez et al. (2013) observed that the better plant growth and fruit yield in grafted 'Josefina' scion under moderate water deficit was mainly due to the drought-tolerant 'Zarina' rootstock. In Turkey, Altunlu and Gul (2012) demonstrated that grafting tomato onto a vigorous rootstock 'Beaufort' provides resistance to drought stress without having a negative effect on yield. Nilsen et al. (2014) found that the rootstock 'Jjak Kkung' reduces the vegetative growth of 'BHN 602' scion to conserve water while maintaining better photosynthetic activity under mild drought stress.

Sometimes, frequent heavy rainfall that occurs during cropping season such as rainy season in tropical and subtropical parts of India causes water logging, resulting in reduction of oxygen in the soil that leads to plant death. In this situation, tomato cultivation in open-fields is challenging. Grafting with suitable rootstocks has been found to alleviate water logging response in tomato. Bhatt et al. (2015) found that in comparison with self- or nongrafted high-yielding tomato 'Arka Rakshak', grafting onto eggplant rootstock 'Arka Keshav', 'Arka Neelkanth', 'BPLH-1', and 'Mattu Gulla' exhibited higher physiological adaptation to waterlogging and gave relatively higher fruit yield. Similarly, Bahadur et al. (2015) observed that grafting onto eggplant rootstock 'IC-111056' and 'IC354557' improved waterlogging tolerance in tomato scion 'Arka Rakshak' and 'Arka Samrat'.

Heavy metal stress tolerance. Presently, high levels of heavy metals and their toxicity in agricultural ecosystems pose a serious threat not only for crop yield but also for environmental and human health. Among all the heavy metals, some are harmful to the plant system even at very low levels, whereas others may accumulate in plant tissues up to a certain level with no noticeable symptoms (Savvas et al., 2010). An ecofriendly, sustainable approach to prevent or reduce heavy metal toxicity would be to graft commercial cultivars onto tolerant rootstocks.

Recently, Kumar et al. (2015a, 2015b, $2015 \mathrm{c})$ studied the response of tomato plants 'Ikram', either nongrafted or self-grafted or grafted onto tomato 'Maxifort' and 'Unifort' and eggplant 'Black Beauty' rootstock to elevated levels ( 25 or $50 \mu \mathrm{M}$ ) of cadmium (Cd) and Ni. The 'Maxifort' rootstockgrafted tomato showed higher tolerance to $\mathrm{Cd}$ or Ni stress that was ascribed to alteration of morphological (high shoot and root dry 
biomass, leaf area, and fruit yield), physiological (high SPAD index and $F_{\mathrm{v}} / F_{\mathrm{m}}$ ratio, and high leaf nutrient availability), and biochemical (low accumulation of oxidative stressors including hydrogen peroxide and malondialdehyde, lower electrolyte leakage, and high antioxidant enzymes) plant processes (Kumar et al., 2015a, 2015b). Furthermore, they also demonstrated that the specific rootstock 'Black Beauty' or 'Maxifort' can reduce the accumulation of $\mathrm{Cd}$ in shoots and edible fruits (Kumar et al., 2015c). In Brazil, Gratao et al. (2015) demonstrated that of the total amount of $\mathrm{Cd}$ taken up by the roots of the rootstock, a larger proportion was retained by the roots and only a small part was translocated to the aboveground parts of the plant. Macronutrient $(\mathrm{Ca}, \mathrm{S}, \mathrm{P}$, and $\mathrm{Mg}$ ) uptake decreased in nongrafted plants, whereas in grafted plants, uptake of macronutrients was not changed. During Cd stress, enhanced activity of CAT, GPX, APX, and glutathione reductase was observed in nongrafted plants; grafted plants revealed distinct trends that clearly indicate signaling responses from the rootstock, allowing sufficient time to activate defense mechanisms in the shoot. According to Savvas et al. (2010), wild eggplant $S$. torvum specifically limits the translocation of $\mathrm{Cd}$ to the shoot rather than limiting Cd uptake. A similar observation was made by Kumar et al. (2015c) in tomato, where $\mathrm{Cd}$ content in the roots of 'Maxifort' rootstock was similar to nongrafted 'Ikram' plants, but the Cd content in the leaves of 'Maxifort'-grafted plants was lower than nongrafted 'Ikram'. However, grafting 'Ikram' onto 'Maxifort' was found to restrict both the uptake and translocation of $\mathrm{Ni}$, as determined by lower $\mathrm{Ni}$ concentration in the roots and leaves, as compared with self-grafted plants (Kumar et al., 2015b). Hence, it is clear that the use of suitable rootstock could restrict the uptake of heavy metals, translocation of heavy metals, or both to plant shoots and edible fruit, thereby reducing heavy metal impact on human health.

Efficient nutrient uptake and translocation. Grafting onto vigorous rootstock contributes to enhanced nutrient uptake and translocation of grafted plants (Savvas et al., 2010). The nutrient status of grafted plants has been positively related to tomato fruit yield (Sánchez-Rodríguez et al., 2014; Kumar et al., 2015a, 2015b). In tomato, calcium (Ca) plays an important role and its deficiency causes the blossom end rot disorder. A significant increase of $\mathrm{Ca}$ concentration was found in the leaves of tomato scions 'Fanny' and 'Goldmar' when grafted onto 'AR-9704' rootstock (Fernandez-Garcia et al., 2004b). Similarly, 'Rita' tomato scion grafted onto 'Beaufort', 'Energy', or 'PG3' rootstock (Leonardi and Giuffrida, 2006) and 'Gorety' and 'Raf' tomato scion grafted onto 'Beaufort' rootstock (Goto et al., 2013) showed a significant increase of $\mathrm{Ca}$ uptake in the grafted plants. The higher accumulation of macro- $(\mathrm{N}, \mathrm{P}, \mathrm{K})$ and micronutrients $(\mathrm{Fe}, \mathrm{Cu})$ was obtained from 'Josefina' scion grafted onto drought-tolerant 'Zarina' (Sánchez-Rodríguez et al., 2014). Grafting involving vigorous rootstock such as 'Maxifort' has been shown to minimize the reduction in accumulation of important elements such as $\mathrm{P}, \mathrm{K}, \mathrm{Ca}, \mathrm{Fe}, \mathrm{Mn}$, and $\mathrm{Zn}$ under Cd stress (Kumar et al., 2015a). Similarly, the 'Maxifort' rootstock has also shown to maintain the nutritional status (leaf $\mathrm{Ca}, \mathrm{Fe}$ and $\mathrm{Cu}$ ) of grafted tomato plants under Ni stress (Kumar et al., 2015b). The water- and nitrogen-use efficiency of field-grown tomato 'Florida 47' was increased when grafted onto vigorous rootstock 'Beaufort' and 'Multifort' (Djidonou et al., 2013a). Therefore, grafting can increase the accumulation of nutrients through enhanced uptake, translocation, or both by vigorous rootstocks both under optimal and suboptimal conditions.

\section{Economic Aspects of Tomato Grafting}

Information on economic viability of grafted plant production is limited. Barrett et al. (2012) estimated the cost at $\$ 0.78$ per grafted plant (including seed, labor, and cost of other materials) for a small nursery production of up to 1000 plants per season. Djidonou et al. (2013b) reported that the estimated cost of grafted and nongrafted seedlings were $\$ 0.67$ and $\$ 0.15$ per plant, respectively, for the production of freshmarket tomato under common management practices in Florida, USA. Although grafting increased the total cost of production up to $\$ 3020.16$ per acre area, the net return also increased by $\$ 253.32-\$ 2458.24$ per acre based on the tomato market prices. The economic analysis conducted by World Vegetable Center, Taiwan, reported that per hectare total cost for grafted tomato cultivation in Vietnam was significantly higher (189.6 million Vietnamese Dong, VND; where $1 \$=\approx 22,725 \mathrm{VND})$ than nongrafted tomato (106.6 million VND). However, the difference in net returns was large enough to make grafted tomato significantly more profitable as the benefit-cost ratio for grafted tomato was 4.6 in comparison with 3.5 for nongrafted tomato (Genova et al., 2013).

Among the variable costs associated with the final price of grafted seedling, labor cost is more important which may vary in different countries. Because of the availability of cheaper labor in large tomato-producing countries such as China and India, the price of grafted plant is expected to be relativity lesser than the United States, most of the European countries, Japan, and Korea. Furthermore, lower price of grafted seedling seems to be more important to make the grafting technology as a viable option, especially for open-field vegetable production (Lewis and Kubota, 2014).

\section{Challenges and Future Thrust}

To allow growers to enjoy the benefits from grafted plants, it is also necessary to consider the production of uniform and healthy grafted seedlings at reasonable prices. The high cost of grafted seedlings is the result of intensive labor input for performing grafting, a longer production period, and the additional cost of the rootstock seed. These expenses often discourage potential use of grafted seedlings. Therefore, research needs to be focused on to considerably reduce the production cost of grafted seedling by mechanization of this technology using efficient automated grafting robots.

Another big challenge for adoption of this technique is that unlike chemical fumigants, grafting provides a site-specific management tool, and its success depends on accurate disease diagnosis and a firm understanding of the pathogen population. Therefore, to achieve successful adoption of this technique at a higher pace, researchers, extension functionaries, and seed companies must collectively do efforts to create awareness of this technology among its various stakeholders. Dissemination of technology to farmers through various extension programs including workshops, fairs, field days, on-farm trials, and latest information communication systems is very important for better outreach to the farmers. Grafting may also be used to supplement tomato classical breeding programs. Future efforts in tomato rootstock breeding should take into consideration the adjustment of rootstock to specific environments, resistance to insects and foliar diseases, improved resistance to abiotic stresses, and increase fruit quality. Most of the tomato grafting employed for pathogens are primarily designed for a specific pathogen except few, where rootstocks provide resistance or tolerance to multiple pathogens. Therefore, future research is needed to explore the capability of managing disease complexes of tomato with grafting. In addition, most of the grafting researches are from greenhouse production systems, and limited information on compatibility with open-field cultivars and field performance of grafted plants in various climatic conditions (Kubota et al., 2008). Therefore, research efforts should also be made to test rootstock performance and compatibility in open-field systems for wider perspectives of the application of this technology.

\section{Literature Cited}

Abdelmageed, A.H.A. and N. Gruda. 2007. Influence of heat shock pretreatment on growth and development of tomatoes under controlled heat stress conditions. J. Appl. Bot. Food Qual. 81:26-28.

Abdelmageed, A.H.A. and N. Gruda. 2009. Influence of grafting on growth, development and some physiological parameters of tomatoes under controlled heat stress conditions. Eur. J. Hort. Sci. 74:16-20.

Albacete, A., C. Martínez-Andújar, M.E. Ghanem, M. Acosta, J. Sánchez-Bravo, M.J. Asins, J. Cuartero, S. Lutts, I.C. Dodd, and F. Pérez-Alfocea. 2009. Rootstock-mediated changes in xylem ionic and hormonal status are correlated with delayed leaf senescence, and increased leaf area and crop productivity in salinized tomato. Plant Cell Environ. 32:928-938.

Altunlu, H. and A. Gul. 2012. Increasing drought tolerance of tomato plants by grafting. Fifth Balkan Symposium on Vegetables and Potatoes 960:183-190.

Bahadur, A., N. Rai, R. Kumar, S.K. Tiwari, A.K. Singh, A.K. Rai, U. Singh, P.K. Patel, V. Tiwari, A.B. Rai, M. Singh, and B. Singh. 2015. Grafting tomato on eggplant as a potential tool to improve waterlogging tolerance in hybrid tomato. Veg. Sci. 42:82-87. 
Barrett, C.E., X. Zhao, and A.W. Hodges. 2012. Cost benefit analysis of using grafted transplants for root-knot nematode management in organic heirloom tomato production. HortTechnology 22:252-257.

Bausher, M.G. 2011. Grafting technique to eliminate rootstock suckering of grafted tomatoes. HortScience 46:596-598.

Bausher, M.G. 2013. Graft angle and its relationship to tomato plant survival. HortScience 48:34-36.

Bhatt, R.M., K.K. Upreti, M.H. Divya, S. Bhat, C.B. Pavithra, and A.T. Sadashiva. 2015. Interspecific grafting to enhance physiological resilience to flooding stress in tomato (Solanum lycopersicum L.). Sci. Hort. 182:8-17.

Black, L.L., D.L. Wu, J.F. Wang, T. Kalb, D. Abbass, and J.H. Chen. 2003. Grafting tomatoes for production in the hot-wet season. AVRDC Publication 3:551.

Bumgarner, N.R. and M.D. Kleinhenz. 2014. Grafting guide - A pictorial guide to the cleft and splice graft methods. Ohio State Univ. Ohio Agr. Res. Dev. Ctr. Bul. 950.

Chaudhari, S., K.M. Jennings, D.W. Monks, D.L. Jordan, C.C. Gunter, N.T. Basinger, and F.J. Louws. 2016a. Response of eggplant (Solanum melongena) grafted onto tomato (Solanum lycopersicum) rootstock to herbicides. Weed Technol. 30:207-216.

Chaudhari, S., K.M. Jennings, D.W. Monks, D.L. Jordan, C.C. Gunter, and F.J. Louws. 2015. Response of grafted tomato (Solanum lycopersicum) to herbicides. Weed Technol. 29:800-809.

Chaudhari, S., K.M. Jennings, D.W. Monks, D.L. Jordan, C.C. Gunter, S.J. McGowen, and F.J. Louws. 2016b. Critical period for weed control in grafted and non-grafted fresh market tomato. Weed Sci. 64:523-530.

Chaudhari, S., K.M. Jennings, D.W. Monks, D.L. Jordan, C.C. Gunter, and F.J. Louws. 2017a. Response of drought-stressed grafted and non-grafted tomato (Solanum Lycopersicum) to postemergence metribuzin. Weed Technol. 31:447-454.

Chaudhari, S., K.M. Jennings, D.W. Monks, D.L. Jordan, C.C. Gunter, and F.J. Louws. 2017b. Absorption, translocation, and metabolism of 14C-halosulfuron in grafted eggplant (Solanum melongena) and tomato (Solanum lycopersicum). Weed Technol. In press.

Chetelat, R.T. and J.P. Petersen. 2003. Improved maintenance of the tomato like Solanum spp. by grafting. TGC $53: 14-15$.

Cohen, S. and A. Naor. 2002. The effect of three rootstocks on water use, canopy conductance and hydraulic parameters of apple trees and predicting canopy from hydraulic conductance. Plant Cell Environ. 25:17-28.

Colla, G., Y. Rouphael, R. Jawad, P. Kumar, E. Rea, and M. Cardarelli. 2013. The effectiveness of grafting to improve $\mathrm{NaCl}$ and $\mathrm{CaCl}_{2}$ tolerance in cucumber. Sci. Hort. 164:380-391.

Colla, G., Y. Rouphael, C. Leonardi, and Z. Bie. 2010. Role of grafting in vegetable crops grown under saline conditions. Sci. Hort. 127:147-155.

Cuartero, J., M.C. Bolarin, M.J. Asins, and V. Moreno. 2006. Increasing salt tolerance in the tomato. J. Expt. Biol. 57:1045-1058.

Cuartero, J. and M.R. Fernandez. 1999. Tomato and salinity. Sci. Hort. 78:83-125.

Davis, A.R., P. Perkins-Veazie, R. Hassell, A. Levi, S.R. King, and X. Zhang. 2008a. Grafting effects on vegetable quality. HortScience 43:1670-1672.

Davis, A.R., P. Perkins-Veazie, Y. Sakata, S. Lopez-Galarza, J.V. Maroto, S.G. Lee, Y.C. Huh, Z.Y. Sun, A. Miguel, S.R. King, R. Cohen, and J.M. Lee. 2008b. Cucurbit grafting. Crit. Rev. Plant Sci. 27:50-74.
Djidonou, D., Z. Gao, and X. Zhao. 2013b. Economic analysis of grafted tomato production in sandy soils in northern Florida. HortTechnology 23:613-621.

Djidonou, D., X. Zhao, E.H. Simonne, and K.E. Koch. 2013a. Yield, water-, and nitrogen-use efficiency in field-grown, grafted tomatoes. HortScience 48:485-492.

Dor, E., B. Alperin, S. Wininger, B. Ben-Dor, V.S. Somvanshi, H. Koltai, Y. Kapulnik, and J. Hershenhorn. 2010. Characterization of a novel tomato mutant resistant to the weedy parasites Orobanche and Phelipanche spp. Euphytica 171:371-380.

Estan, M.T., M.M. Martinez-Rodriguez, F. PerezAlfocea, T.J. Flowers, and M.C. Bolarin. 2005. Grafting raises the salt tolerance of tomato through limiting the transport of sodium and chloride to the shoot. J. Expt. Bot. 56:703-712.

Estan, M.T., I. Villalta, M.C. Bolarin, E.A. Carbonell, and M.J. Asins. 2009. Identification of fruit yield loci controlling the salt tolerance conferred by solanum rootstocks. Theor. Appl. Genet. 118:305-312.

FAOSTAT. 2008. Database. Mar. 2017. <http:// www.fao.org/faostat/en/\#data/QC>

FAOSTAT. 2014. Database. Mar. 2017. <http:// www.fao.org/faostat/en/\#data/QC>.

Fernandez-Garcia, N., M. Carvajal, and E. Olmos. 2004a. Graft union formation in tomato plants: Peroxidase and catalase involvement. Ann. Bot. (Lond.) 93:53-60.

Fernandez-Garcia, N., A. Cerda, and M. Carvajal. 2003. Grafting, a useful technique for improving salinity tolerance of tomato? Proc. Intl. Symp. Managing Greenhouse Crops Saline Environ. 609:251-256.

Fernandez-Garcia, N., V. Martinez, and M. Carvajal. 2004b. Effect of salinity on growth, mineral composition, and water relations of grafted tomato plants. J. Plant Nutr. Soil Sci. 167:616622.

Flores, F.B., P. Sanchez-Bel, M.T. Estan, M.M. Martinez-Rodriguez, E. Moyano, B. Morales, J.F. Campos, J.O. Garcia-Abellan, M.I. Egea, N. Fernandez-Garcia, F. Romojaro, and M.C. Bolarin. 2010. The effectiveness of grafting to improve tomato fruit quality. Sci. Hort. 125:211-217.

Flowers, T.J. 2004. Improving crop salt tolerance. J. Expt. Bot. 55:307-319.

Freeman, J.H., T. McAvoy, S. Rideout, and A. Wimer. 2010. Utilization of grafted tomato seedlings for open field production. HortScience 45:499.

Garibaldi, A., M. Baudino, A. Minuto, and M.L. Gullino. 2008. Effectiveness of fumigants and grafting against tomato brown root rot caused by Colletotrichum coccodes. Phytoparasitica 36:483-488.

Genova, C., P. Schreinemachers, and V. Afari-Sefa. 2013. An impact assessment of AVRDC's tomato grafting in Vietnam. AVRDC - The World Vegetable Center, Shanhua, Taiwan. AVRDC Publication No. 13-773.

Ghosheh, H., M. Al-Kawamleh, and I. Makhadmeh. 2010. Weed competitiveness and herbicidal sensitivity of grafted tomatoes (Solanum lycopersicon Mill.). J. Plant Prot. Res. 50:307-313.

Gilardi, G., P. Colla, M. Pugliese, M. Baudino, M.L. Gullino, and A. Garibaldi. 2014. Control of Colletotrichum coccodes on tomato by grafting and soil amendments. J. Phytopathol. 162:116-123.

Goto, R., A. de Miguel, J. Ignacio Marsal, E. Gorbe, and A. Calatayud. 2013. Effect of different rootstocks on growth, chlorophyll a fluorescence and mineral composition of two grafted scions of tomato. J. Plant Nutr. 36:825-835.

Gousset, C., C. Collonnier, K. Mulya, I. Mariska, G.L. Rotino, P. Besse, A. Servaes, and D. Sihachakr. 2005. Solanum torvum, as a useful source of resistance against bacterial and fungal diseases for improvement of eggplant ( $S$. melongena L.). Plant Sci. 168:319-327.

Gratao, P.L., C.C. Monteiro, T. Tiago, R.F. Carvalho, R.L. Alves, P.L. Peters, and R.A. Azevedo. 2015. Cadmium stress antioxidant responses and rootto-shoot communication in grafted tomato plants. Biometals 28:803-816.

Guan, W. and S. Hallet. 2016. Vegetable grafting technique for tomato grafting. Horticulture and Landscape Architecture. $<$ Ag.purdue.edu/HLA $>$.

Guan, W., X. Zhao, R. Hassell, and J. Thies. 2012. Defense mechanisms involved in disease resistance of grafted vegetables. HortScience 47:164-170.

Hanna, H.Y. 2012. Producing a grafted and a nongrafted tomato plant from the same seedling. HortTechnology 22:72-76.

He, Y., Z. Zhu, J. Yang, X. Ni, and B. Zhu. 2009. Grafting increases the salt tolerance of tomato by improvement of photosynthesis and enhancement of antioxidant enzymes activity. Environ. Expt. Bot. 66:270-278.

Huang, W., S. Liao, H. Lv, A.B.M. Khaldun, and Y. Wang. 2015a. Characterization of the growth and fruit quality of tomato grafted on a woody medicinal plant, Lycium chinense. Sci. Hort. 197:447-453.

Huang, Y., Q.S. Kong, F. Chen, and Z.L. Bie. 2015b. The history, current status and future prospects of vegetable grafting in China. Acta Hort. 1086:31-39.

Huh, Y.C., Y.H. Woo, J.M. Lee, and Y.H. Om. 2003. Growth and fruit characteristics of watermelon grafted onto Citrullus rootstocks selected for disease resistance. J. Korean Soc. Hort. Sci. 44:649-654.

Iseri, O.D., D.A. Körpe, F.I. Sahin, and M. Haberal. 2015. High salt induced oxidative damage and antioxidant response in tomato grafted on tobacco. Chil. J. Agr. Res. 75:192-201.

Johnson, S., P. Kreider, and C. Miles. 2011. Vegetable grafting - Eggplants and Tomatoes. Washington State Univ., WSU Mount Vernon Northwestern Washington Res. Ext. Ctr., Fact Sheet FS052E. 03 July 2013.

Kacjan-Marsic, N. and J. Osvald. 2004. The influence of grafting on yield of two tomato cultivars (Lycopersicon esculentum Mill.) grown in a plastic house. Acta Agr. Slov. 83:243-249.

Kaskavalci, G., Y. Tuzel, O. Dura, and G.B. Oztekin. 2009. Effects of alternative control methods against Meloidogyne incognita in organic tomato production. Ekoloji 18:23-31.

Kawaguchi, M., A. Taji, D. Backhouse, and M. Oda. 2008. Anatomy and physiology of graft incompatibility in solanaceous plants. J. Hort. Sci. Biotechnol. 83:581-588.

Khah, E.M., E. Kakava, A. Mavromatis, D. Chachalis, and C. Goulas. 2006. Effect of grafting on growth and yield of tomato (Lycopersicon esculentum Mill.) in greenhouse and open-field. J. Appl. Hort. 8:3-7.

King, S.R., A.R. Davis, W. Liu, and A. Levi. 2008. Grafting for disease resistance. HortScience 43:1673-1676.

Krumbein, A. and D. Schwarz. 2013. Grafting: A possibility to enhance health-promoting and flavor compounds in tomato fruits of shaded plants? Sci. Hort. 149:97-107.

Kubota, C. 2015. Overview of vegetable grafting in the U.S. Fourth National Vegetable Grafting 
Symposium. Vegetable Grafting- Research Based Information Portal. 17 Aug. 2017. $<$ http://www.vegetablegrafting.org/wp/wp-content/ uploads/2016/01/Kubota.pdf $>$.

Kubota, C., M.A. McClure, N. Kokalis-Burelle, M.G. Bausher, and E.N. Rosskopf. 2008. Vegetable grafting: History, use, and current technology status in North America. HortScience 43:1664-1669.

Kumar, P., M. Edelstein, M. Cardarelli, E. Ferri, and G. Colla. 2015c. Grafting affects growth, yield, nutrient uptake, and partitioning under cadmium stress in tomato. HortScience 50:1654-1661.

Kumar, P., L. Lucini, Y. Rouphael, M. Cardarelli, R.M. Kalunke, and G. Colla. 2015a. Insight into the role of grafting and arbuscular mycorrhiza on cadmium stress tolerance in tomato. Front. Plant Sci. 6:477.

Kumar, P., Y. Rouphael, M. Cardarelli, and G. Colla. 2015b. Effect of nickel and grafting combination on yield, fruit quality, antioxidative enzyme activities, lipid peroxidation, and mineral composition of tomato. J. Plant Nutr. Soil Sci. 178:848-860.

Kumar, P., Y. Rouphael, M. Cardarelli, and G. Colla. 2017. Vegetable grafting as a tool to improve drought resistance and water use efficiency. Front. Plant Sci. 8:1130.

Kunwar, S., M.L. Paret, S.M. Olson, L. Ritchie, J.R. Rich, J.H. Freeman, and T. McAvoy. 2015. Grafting rootstocks with resistance to Ralstonia solanacearum against Meloidogyne incognita in tomato production. Plant Dis. 99:119-124.

Lee, J.M. 1994. Cultivation of grafted vegetables: Current status, grafting methods, and benefits. HortScience 29:235-239.

Lee, J.M. 2003. Advances in vegetable grafting. Chron. Hort. 43:13-19.

Lee, S.G. 2007. Production of high quality vegetable seedling grafts. Acta Hort. 759:169-174.

Lee, J.M., C. Kubota, S.J. Tsao, Z. Bie, P.H. Echevarria, L. Morra, and M. Oda. 2010. Current status of vegetable grafting: Diffusion, grafting techniques, automation. Sci. Hort. 127:93-105.

Lee, J.M. and M. Oda. 2003. Grafting of herbaceous vegetable and ornamental crops. Hort. Rev. 28:61-124.

Leonardi, C. and F. Giuffrida. 2006. Variation of plant growth and macronutrient uptake in grafted tomatoes and eggplants on three different rootstocks. Eur. J. Hort. Sci. 71:97-101.

Lewis, M. and C. Kubota. 2014. Scenario-based cost analysis for vegetable grafting nurseries of different technologies and sizes. HortScience 49:917-930

Lian, D., Z. Lingzhi, L. Liying, and R. Hua-zhong. 2007. Effects of different rootstocks with resistance to root-knot nematode on growth, quality and yield of tomato in greenhouse. China Vegetables 6:13-16.

Lin, C., S. Hsu, K. Tzeng, and J. Wang. 2008. Application of a preliminary screen to select locally adapted resistant rootstock and soil amendment for integrated management of tomato bacterial wilt in Taiwan. Plant Dis. 92:909-916.

Lin, K.R., C.C. Weng, H.F. Lo, and J.T. Chen. 2004. Study of the root antioxidative system of tomatoes and eggplants under waterlogged conditions. Plant Sci. 167:355-365.

Lopez-Perez, J.A., M. Le Strange, I. Kaloshian, and A.T. Ploeg. 2006. Differential response of mi gene-resistant tomato rootstocks to root-knot nematodes (Meloidogyne incognita). Crop Prot. 25:382-388.
Louws, F.J. 2012. IPM diversification: Advancing the science and practice of grafting tomatoes to manage soilborne pathogens. Proc. Amer. Phytopathol. Soc. 102:153.

Louws, F.J., C.L. Rivard, and C. Kubota. 2010 Grafting fruiting vegetables to manage soilborne pathogens, foliar pathogens, arthropods and weeds. Sci. Hort. 127:127-146.

Matsuzoe, N., H. Nakamura, H. Okubo, and K. Fujieda. 1993b. Growth and yield of tomato plants grafted on Solanum rootstocks. J. Jpn. Soc. Hort. Sci. 61:847-855.

Matsuzoe, N., H. Okubo, and K. Fujieda. 1993a. Resistance of tomato plants grafted on Solanum rootstocks to bacterial wilt and root-knot nematode. J. Jpn. Soc. Hort. Sci. 61:865-872.

McAvoy, T., M. Paret, J.H. Freeman, S. Rideout, and S.M. Olson. 2012. Evaluation of grafting using hybrid rootstocks for management of bacterial wilt in field tomato production. HortScience 47:621-625.

Medina-Filho, H.P. and M.A. Stevens. 1980. Tomato breeding for nematode resistance: Survey of resistant varieties for horticultural characteristics and genotype of acid phosphates. Acta Hort. 100:383-391.

Minuto, A., G. Gilardi, M.L. Gullino, and A. Garibaldi. 2008. Increasing severity of attacks of Colletotrichum coccodes on grafted tomatoes. Acta Hort. 789:101-106.

Muneer, S., C.H. Ko, H. Wei, Y. Chen, and B.R. Jeong. 2016. Physiological and proteomic investigations to study the response of tomato graft unions under temperature stress. PLoS One 11(6): 0157439.

Nicoletto, C., F. Tosini, and P. Sambo. 2013. Effect of grafting and ripening conditions on some qualitative traits of 'cuore di bue' tomato fruits. J. Sci. Food Agr. 93:1397-1403.

Nilsen, E.T., J. Freeman, R. Grene, and J. Tokuhisa. 2014. A rootstock provides water conservation for a grafted commercial tomato (Solanum lycopersicum L.) line in response to milddrought conditions: A focus on vegetative growth and photosynthetic parameters. PLoS One 9(12):e115380.

Ntatsi, G., D. Savvas, H.P. Kläring, and D. Schwarz. 2014. Growth, yield, and metabolic responses of temperature-stressed tomato to grafting onto rootstocks differing in cold tolerance. J. Amer. Soc. Hort. Sci. 139:230-243.

Ntatsi, G., D. Savvas, and D. Schwarz. 2011. Role of abscisic acid in the adaptation of grafted tomato to moderately suboptimal temperature stress. In International Symposium on Advanced Technologies and Management Towards Sustainable Greenhouse Ecosystems: Greensys 2011 952:295-302.

Oda, M. 1995. New grafting method for fruitbearing vegetables in Japan. Jpn. Agr. Res. Q. 29:187-194.

Oda, M. 2007. Vegetable seedling grafting in Japan. Acta Hort. 759:175-180.

Oda, M., M. Maruyama, and G. Mori. 2005. Water transfer at graft union of tomato plants grafted onto Solanum rootstocks. J. Jpn. Soc. Hort. Sci. $74: 458-463$.

Oda, M., M. Nagata, K. Tsuji, and H. Sasaki. 1996. Effects of Scarlet eggplant rootstock on growth, yield, and sugar content of grafted tomato fruits. J. Jpn. Soc. Hort. Sci. 65:531536.

Oztekin, G.B., F. Giuffrida, Y. Tuzel, and C. Leonardi. 2009. Is the vigour of grafted tomato plants related to root characteristics? J. Food Agr. Environ. 7:364-368.
Oztekin, G.B. and Y. Tuzel. 2011. Salinity response of some tomato rootstocks at seedling stage. Afr. J. Agr. Res. 6:4726-4735.

Petran, A. and E. Hoover. 2014. Solanum torvum as a compatible rootstock in interspecific tomato grafting. J. Hort. 1:103.

Pogonyi, A., Z. Pek, L. Helyes, and A. Lugasi. 2005. Effect of grafting on the tomato's yield, quality and main fruit components in spring forcing. Acta Aliment. 34:453-462.

Riga, P. 2015. Effect of rootstock on growth, fruit production and quality of tomato plants grown under low temperature and light conditions. Hort. Environ. Biotechnol. 56:626-638.

Rivard, C.L. and F.J. Louws. 2006. Grafting for disease resistance in heirloom tomatoes. North Carolina Coop. Ext. Serv. Bul. Ag-675. North Carolina Cooperative Extension Service, Raleigh, NC. 8 p.

Rivard, C.L. and F.J. Louws. 2008. Grafting to manage soilborne diseases in heirloom tomato production. HortScience 43:2104-2111.

Rivard, C.L., S. O'Connell, M.M. Peet, and F.J. Louws. 2010. Grafting tomato with interspecific rootstock to manage diseases caused by Sclerotium rolfsii and southern root-knot nematode. Plant Dis. 94:1015-1021.

Rivard, C.L., S. O'Connell, M.M. Peet, R.M. Welker, and F.J. Louws. 2012. Grafting tomato to manage bacterial wilt caused by Ralstonia solanacearum in the southeastern United States. Plant Dis. 96:973-978.

Rivero, R.M., J.M. Ruiz, and L. Romero. 2003a. Can grafting in tomato plants strengthen resistance to thermal stress? J. Sci. Food Agr. 83:1315-1319.

Rivero, R.M., J.M. Ruiz, E. Sanchez, and L. Romero. 2003b. Does grafting provide tomato plants an advantage against $\mathrm{H}_{2} \mathrm{O}_{2}$ production under conditions of thermal shock? Physiol. Plant. 117:44-50.

Rylski, I. 1972. Effect of the early environment on flowering in pepper (Capsicum annuum L.). J. Amer. Soc. Hort. Sci. 97:648-651.

Sánchez-Rodríguez, E., R. Leyva, C. ConstánAguilar, L. Romero, and J.M. Ruiz. 2014. How does grafting affect the ionome of cherry tomato plants underwater stress? Soil Sci. Plant Nutr. 60:145-155.

Sánchez-Rodríguez, E., L. Romero, and M.J. Ruiz. 2013. Role of grafting in resistance to water stress in tomato plants: Ammonia production and assimilation. J. Plant Growth Regul. 32:831-842.

Santa-Cruz, A., M.M. Martinez-Rodriguez, J. Cuartero, and M.C. Bolarin. 2001. Response of plant yield and ion contents to salinity in grafted tomato plants. Acta Hort. 559:413417.

Santa-Cruz, A., M.M. Martinez-Rodriguez, F. Perez-Alfocea, R. Romero-Aranda, and M.C. Bolarin. 2002. The rootstock effect on the tomato salinity response depends on the shoot genotype. Plant Sci. 162:825-831.

Savvas, D., G. Colla, Y. Rouphael, and D. Schwarz. 2010. Amelioration of heavy metal and nutrient stress in fruit vegetables by grafting. Sci. Hort. 127:156-161.

Savvas, D., A. Savva, G. Ntatsi, A. Ropokis, I. Karapanos, A. Krumbein, and C. Olympios. 2011. Effects of three commercial rootstocks on mineral nutrition, fruit yield, and quality of salinized tomato. J. Plant Nutr. Soil Sci. 174:154-162.

Schwarz, D., Y. Rouphael, G. Colla, and J.H. Venema. 2010. Grafting as a tool to improve tolerance of vegetables to abiotic stresses: 
Thermal stress, water stress and organic pollutants. Sci. Hort. 127:162-171.

Scott, J.W., J. Wang, and P. Hanson. 2005. Breeding tomatoes for resistance to bacterial wilt, a global view. Intl. Symp. Tomato Dis. Orlando, FL. p. 161-172.

Turhan, A., N. Ozmen, M.S. Serbeci, and V. Seniz. 2011. Effects of grafting on different rootstocks on tomato fruit yield and quality. Hort. Sci. (Prague) 38:142-149.

Van der Ploeg, A. and E. Heuvelink. 2005. Influence of sub-optimal temperature on tomato growth and yield: A review. J. Hort. Sci. Biotechnol. 80:652-659.

Venema, J.H., B.E. Dijk, J.M. Bax, P.R. van Hasselt, and J.T.M. Elzenga. 2008. Grafting tomato (Solanum lycopersicum) onto the rootstock of a high-altitude accession of Solanum habrochaites improves suboptimaltemperature tolerance. Environ. Expt. Bot. 63:359-367.

Venema, J.H., F. Posthumus, and P.R. van Hasselt. 1999. Impact of suboptimal temperature on growth, photosynthesis, leaf pigments and carbohydrates of domestic and high-altitude wild Lycopersicon species. J. Plant Physiol. 155:711-718.

Vrcek, I.V., M. Samobor, M. Bojic, M. Medic-Saric, R. Vukobratovic, R. Erhatic, D. Horvat, and Z. Matotan. 2011. The effect of grafting on the antioxidant properties of tomato (Solanum lycopersicum L.). Span. J. Agr. Res. 9:844-851.
Vu, N.T., S.H. Kim, T.D. Pham, and I.S. Kim. 2015. Effect of grafting position, water content in substrate on the survival rate and quality of grafted tomato seedlings. J. Agr. Life Environ. Sci. 27:8-13.

Wang, Y.Q. 2011. Plant grafting and its application in biological research. Chin. Sci. Bul. 56:35113517.

Williamson, V.M. 1998. Root-knot resistance genes in tomato and their potential for future use. Annu. Rev. Phytopathol. 36:277293.

Yetisir, H., N. Sari, and S. Yucel. 2003. Rootstock resistance to fusarium wilt and effect on watermelon fruit yield and quality. Phytoparasitica 31:163-169. 